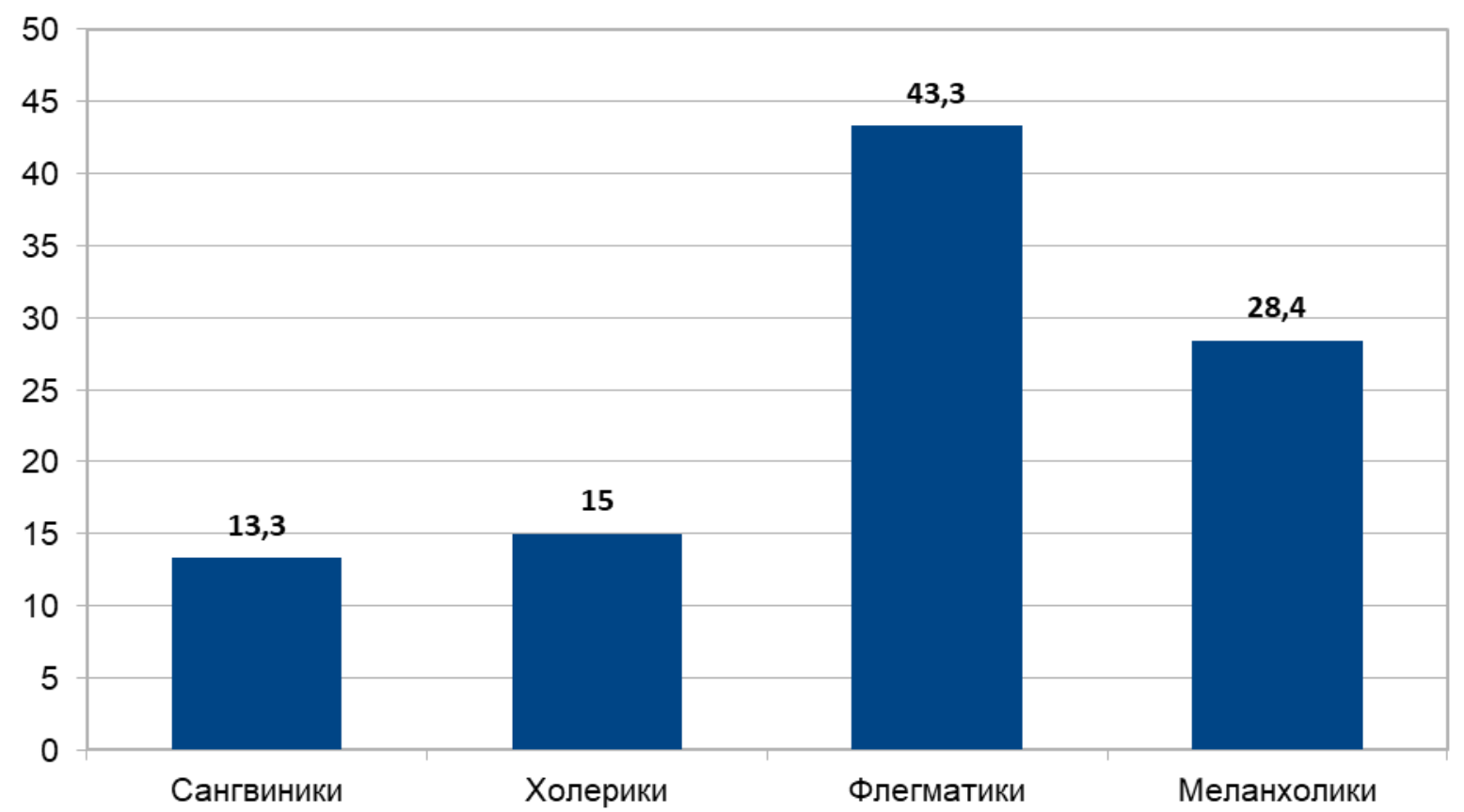

Рисунок 4. Распределения школьников 8 классов по типу темперамента (\%)

Из таблицы 4 и рисунка 4 видно, что среди учащихся 8 классов преобладают флегматики - 43,3 \% (26 человек). Далее следуют по количеству меланхолики - 28,4 \% (17 человек). Количество холериков составило $15 \%$ (9 человек). Количество сангвиников - 13,3 $\%$ (8 человек).

Таким образом, среди учащихся 8 классов преобладают флегматики и меланхолики.

$* * *$

1. Воронкова Е. Д. ОСОБЕННОСТИ ТЕМПЕРАМЕНТА МЛАДШИХ ШКОЛЬНИКОВ И ИХ УЧЁТ В ПРОЦЕССЕ ОБУЧЕНИЯ // Наука и Образование. - 2018. - Т. 1. - №. 1.

2. Умбеталиева А. М. и др. УЧЕТ ОСОБЕННОСТЕЙ ТЕМПЕРАМЕНТА ОБУЧАЮЩИХСЯ В ПРОЦЕССЕ УЧЕБНОЙ ДЕЯТЕЛЬНОСТИ // International Scientific and Practical Conference World science. - ROST, 2017. T. 4. - №. 4. - C. 54-59.

Киньябулатов А.У., Шарафутдинова Н.Х., Суфияров И.Ф., Мухамадеева О.Р., Матузов Г.Л., Кахоров С.А., Тукаев А.Ф.

Музейная экспозиция педиатрического факультета Башкирского государственного медицинского университета (к 60-летию образования факультета)

Башкирский государственный медицинский университет

doi: 10.18411/trnio-11-2021-158

(Россия, Уфа)

\title{
Аннотация
}

За 60 лет своего существования педиатрический факультет Башкирского государственного медицинского университета подготовил более 10 тысяч врачей-педиатров, профессионалов высокого уровня, которые внесли существенный вклад в развитие здравоохранения Республики Башкортостан и Российской Федерации. Создание музейной экспозиции о педиатрическом факультете стало вехой в медицинском музееведении Башкирского государственного медицинского университета.

Ключевые слова: музейная экспозиция, педиатрический факультет, Башкирский государственный медицинский университет, история медицины. 
Abstract

For 60 years of its existence, the Pediatric Faculty of Bashkir State Medical University has trained more than 10 thousand pediatricians, high-level professionals who have made a significant contribution to the development of healthcare in the Republic of Bashkortostan and the Russian Federation. The creation of a museum exhibition about the pediatric faculty has become a milestone in the medical museology of the Bashkir State Medical University.

Keywords: museum exposition, Faculty of Pediatrics, Bashkir State Medical University, History of Medicine.

В 2019 году в Башкирском государственном медицинском университете был открыт, вновь отстроенный на месте прежнего, корпус №3 по улице Ленина, 1. В данном корпусе расположилась кафедра общественного здоровья и организации здравоохранения с курсом ИДПО, отдел работы с иностранными студентами. В октябре 2021 года в фойе 2-го этаже разместили большую музейную экспозицию, посвященную 60-летнему юбилею организации педиатрического факультета. Шесть секций за стеклянным фасадом сразу сделали предположение, что необходимо разбить экспозицию на 6 периодом (по десятилетиям). Большую роль в организации педиатрического факультета сыграл директор Башкирского государственного медицинского института имени15-летия ВЛКСМ (1951-1965 гг.), доцент Н.Ф. Воробьёв, который инициировал предложение об открытии второго (педиатрического) факультета. Предложение было последовательно поддержано министрами здравоохранения БАССР С.3. Лукмановым и М.Х. Камаловым. Директор БГМИ имени 15-летия ВЛКСМ Н.Ф. Воробьёв выдвинул кандидатуру Е.Н. Третьяковой на должность декана педиатрического факультета, которая была поддержана Учёным Советом БГМИ. Большой вклад в подготовку первых педиатров внесли многие преподаватели БГМИ, в т.ч. профессора С.В. Базанова, Н.Т. Бикбулатов, А.Ф. Валиахметов, Н.Г. Гатауллин, Л.Д. Гатауллина, М.Г. Гимранов, Н.Н. Глебова, А.-С.Г. Давлетов, Н.А. Завьялова, З.Ш. Загидуллин, Б.Б. Кудашнв, С.З. Лукманов, Г.С, Максимов, Е.А. Медведева, Н.И. Мельников, А.С. Мифтахова, Р.Ю. Мухаметов, В.В. Петровский, В.М. Романкевич, В.А. Самцов, Г.Н. Терегулов, Е.Н. Третьякова, М.Н. Фридман, Н.С. Шиманов и др. Поэтому указанные профессора и организаторы здравоохранения отображены на фотографиях (коллективные, групповые персональные) [1]. Формирование педиатрии, как науки, в Башкортостане началось во 2-й половине 20 -х гг. ХХ века с изучения причин младенческой смертности и поиска путей её снижения (А.И. Доброхотова, Г.В. Голубцов). Выставлены портреты профессоров А.И. Доброхотовой, Г.В. Голубцова. Деканат педиатрического факультета размещается в корпусе №2, в котором в XIX веке размещалась мужская гимназия - поэтому выставлены исторические фотографии мужской гимназии XIX века. Музейные экспозиции в БГМУ стали хорошей традицией к юбилеям факультетов [2]. В 1934 году в БГМИ была открыта кафедра детских болезней, в приоритете научных исследований была разработка методов диагностики, лечения и борьбы с дизентерией и дифтерией (Г.В. Голубцов, М.Г.Н. Мухамедов, Е.Н. Третьякова). С организацией в 1961 году педиатрического факультета под руководством Е.Н. Третьяковой изучались патогенез и клиника ревматизма, пневмонии и др. бронхолёгочных заболеваний, вопросы санаторно-курортного лечения и диететики детского возраста. В 70-80-е гг. под руководством профессора Л.Д. Гатауллиной разработаны региональные стандарты физического развития детей в возрасте до 14 лет. Проводились исследования в области кардиоревматологии (Х.Ш. Абдурашитова, Ф.К. Андаржанов, Г.Н. Богданова, Л.А. Фаезова и др.); создана методика поэтапного лечения и круглогодичной бициллиномедикаментозной профилактики ревматизма (С.Е. Беляев). Исследовались хронические неспецифические заболевания органов дыхания (А.Е. Казан, В.В. Климанов, М.И. Литвина), в т.ч. при муковисцидозе (О.К. Байков, Н.Ш. Малиевская), аллергозах (М.П. Соколова), клиника и отдаленные последствия туберкулёзного менингита (А.3. Гимранова, Л.В. Макарова и др.), патогенез заболеваний желудочно-кишечного тракта (М.А. Бычкова, Н.А. Ивлева и др.), экссудативного диатеза (Д.Н. Еникеева), дизентерии (Макарова), вирусного гепатита (Н.А. Касимовская), эпидемического паротита (Р.Х. Тенишева) и др.; разрабатывались методы оценки функции щитовидной железы 
(О.К. Байков) и активности лёгочного процесса (А.С. Амосова) при бронхиальной астме. В 1972 году открылась Республиканская детская клиническая больница. В 80-90-е гг. изучались вопросы ранней диагностики, клиники и профилактики эндокринологических заболеваний (Б.С. Годун, Т.Р. Гумерова, М.Г. Давыдович, Р.Г. Еникеев, Ф.Г. Садыков). Все данные работы нашли отражения в виде монографий, буклетов, брошюр и памяток, которые выставлены соответственно периодам исторической хронологии развития педиатрического факультета. В детском артрологическом центре (1987) РДКБ исследовались распространённость, совершенствуются методы лечения и реабилитации больных при ревматоидном артрите (Т.Б. Хайретдинова, Л.В. Яковлева). Изучалось состояние здоровья детей, проживающих в условиях урбанизированной среды и экологического неблагополучия (Э.Н. Ахмадеева, Н.А. Подкользина), распространенность и структура гематологических, нефрологических и кардиоревматологических заболеваний (Г.М. Ардуванова, 3.М. Еникеева и др.). Исследовались социальные аспекты младенческой смертности (Х.Ш. Абдуллина, 3.А.Хуснутдинова), совершенствовалась организация медицинской помощи детям (С.Ш. Мурзабаева, М.М. Назметдинова, И.М. Харисова, Р.Ш. Хасанов и др.). С 1988 года внедряется неонатальный скрининг на наследственные болезни, с 1999 года - система генетического мониторинга врожденных пороков развития в Центре медико-генетической консультации. Изучаются вопросы патологии у новорождённых и детей раннего возраста (Э.Н. Ахмадеева, В.М. Фахрисламова) ставшие новой вехой в неонатологии. С 2000 года в БГМУ ведутся исследования в области уронефрологии (3.Х. Ахметшин, Р.3. Ахметшин и др.), кардиоревматологии (В.А. Малиевский, А.Г. Муталов, Т.Б. Хайретдинова, Л.В. Яковлева), эндокринологии (О.А. Малиевский, Д.С. Нурмухаметова), пульмонологии (Г.В, Байкова, Д.Э. Байков, Р.Ф. Гатиятуллин, Э.И. Эткина и др.), гастроэнтерологии (Р.А. Ахметова, Н.А. Дружинина, А.А. Нижевич), иммунологии, аллергологии (Р.М. Файзуллина, Р.М. Хайруллина и др.), онкогематологии (Б.К. Авзалетдинов, О.Н. Липатов, Э.В. Якупова) детского возраста и др.; физиологии и региональных особенностей развития детей различного возраста (Э.Ф. Киреева, М.Ю. Павлова, Х.3. Шубина), детей-инвалидов (С.В. Шагарова). Многопрофильную специализированную лечебно-консультативную медицинскую помощь детям в РБ оказывают около 30 лечебнодиагностических центров, детские санаторно-курортные учреждения. Экспозиция 10 портретов деканов педиатрического факультета с краткой справкой-биографией сочетается с историческими этапами развития педиатрической службы. Большую помощь в организации музейной экспозиции педиатрического факультета оказали студенты 4 курса П 411 группы: Р.М. Арсланов, А.Р.Афлатонов, Д.И. Зарипов, А.Ф. Тукаев [3].

$$
* * *
$$

1. Педиатрия. Башкортостан. XXI век. Павлов В.Н., Киньябулатов А.У., Суфияров И.Ф., Шарафутдинова Н.Х., Азнабаев Б.М. Уфа, БГМУ, 2016.- 90 с.

2. Киньябулатов А.У., Гончаров А.В., Нуриманов Р.З., Галимова А.М., Галимова Р.А., Шамсутдинов С.М., Каримов М.А. Музей стоматологии Башкирского государственного медицинского университета как воспитательная среда для формирования врача. Казанская наука. 2017. № 4. С. 123-125.

3. Киньябулатов А.У., Суфияров И.Ф., Ракаева Л.Р., Тукаев А.Ф., Шакиров А.Р. Социологический портрет обучающихся педиатрического факультета Башкирского государственного медицинского университета (к 60-летию педиатрического факультета). Уфа: ФГБОУ ВО БГМУ Минздрава России, 2021. — 40 с.

\section{Кирюшин И.И. \\ Формирование профессиональных компетенций у обучающихся системы МВД России средствами цифровых технологий}

Барнаульский юридический институт МВД России

(Россия, Барнаул)

doi: 10.18411/trnio-11-2021-159

\section{Аннотация}

В статье раскрыты этапы формирования профессиональных компетенций у обучающихся в образовательных организациях системы МВД России средствами цифровых 